\title{
Space-time description of dengue outbreaks in Cruzeiro, São Paulo, in 2006 and 2011
}

\author{
Renata Marzzano de Carvalho ${ }^{1}$, Luiz Fernando Costa Nascimento ${ }^{*}$ \\ ${ }^{1}$ Doctor of Health Sciences. Department of Mechanical Engineering. Faculty of Engineering of Guaratinguetá. São Paulo State University (Unesp), São José do Rio Preto, SP, Brazil. \\ 2Doctor of Public Health. Department of Medicine. University of Taubaté, Taubaté, SP, Brazil
}

Study conducted at the University of Taubaté, Taubaté, SP

Article received: $7 / 3 / 2013$ Accepted for publication: $2 / 3 / 2014$

${ }^{*}$ Correspondence: Address: Rua Durval Rocha, 500 Vila Paraíba

Postal Code: 12515-710 Guaratinguetá - SP

Phone: +5512 3125-1103

Fax: +55 12 3621-8796

luiz.nascimento@unitau.com.br

http://dx.doi.org/10.1590/1806-9282.60.06.016

Conflict of interest: none

\section{SUMmarY}

Objective: to identify patterns in the spatial and temporal distribution of cases of dengue fever occurring in the city of Cruzeiro, state of São Paulo (SP).

Methods: an ecological and exploratory study was undertaken using spatial analysis tools and data from dengue cases obtained on the SinanNet. The analysis was carried out by area, using the IBGE census sector as a unit. The months of March to June 2006 and 2011 were assessed, revealing progress of the disease. TerraView 3.3.1 was used to calculate the Global Moran's I, month to month, and the Kernel estimator.

Results: in the year 2006, 691 cases of dengue fever (rate of 864.2 cases/100,000 inhabitants) were georeferenced; and the Moran's I and p-values were significant in the months of April and May $\left(\mathrm{I}_{\mathrm{M}}=0.28 ; \mathrm{p}=0.01 ; \mathrm{I}_{\mathrm{M}}=0.20 ; \mathrm{p}=0.01\right)$ with higher densities in the central, north, northeast and south regions. In the year 2011,654 cases of dengue fever (rate of 886.8 cases/100,000 inhabitants) were georeferenced; and the Moran's I and p-values were significant in the months of April and May $\left(I_{M}=0.28 ; p=0.01 ; I_{M}=0.16 ; p=0.05\right)$ with densities in the same regions as 2006. The Global Moran's I is a global measure of spatial autocorrelation, which indicates the degree of spatial association in the set of information from the product in relation to the average. The I varies between -1 and +1 and can be attributed to a level of significance (p-value). The positive value points to a positive or direct spatial autocorrelation.

Conclusion: we were able to identify patterns in the spatial and temporal distribution of dengue cases occurring in the city of Cruzeiro, SP, and locate the census sectors where the outbreak began and how it evolved.

Keywords: dengue, geographic information systems, epidemiological surveillance, ecological study, spatial distribution of the population.

\section{INTRODUCTION}

In the 1980's, new cases of dengue were reported in Brazil $^{1}$ and in the state of São Paulo, and in 1986 dengue was defined as a disease requiring compulsory notification. ${ }^{2}$ The Vale do Paraíba suffered a dengue outbreak in 2002, on the state's northern coast, municipality of São Sebastião, with 972 indigenous contaminations. ${ }^{3,4}$

A study conducted in the city of São José do Rio Preto between September 2001 and August 2006 using a spatial approach enabled the identification of areas at higher risk for the occurrence of dengue fever, concentrated in the north part of the city. The geocoding process was obtained through equalization of the addresses of dengue cases with the segment map supplied by the city hall. ${ }^{5}$
Georeferencing and spatial analysis techniques have been increasingly used to assess the distribution of vectors and diseases transmitted by them, contributing to improved surveillance and control activities. Its greatest use is to outline strategies dependent upon the different realities of which the city is composed. Thus, the use of these tools enables the identification of risk areas that deserve intensification and/or prioritization of control measures. Souza-Santos \& Carvalho ${ }^{6}$ demonstrated that the analysis of spatial data is an important tool in the surveillance and control not only of Aedes aegypti, but other insect vectors.

In the same manner, we can cite articles by Barbosa and Lourenço ${ }^{7}$ which verified that the incorporation of 
geoprocessing and spatial analysis techniques in the program, provided that these are used immediately after conducting the activities, can contribute to control actions, indicating the spatial clusters with greater incidence. Carvalho and Nascimento, ${ }^{8}$ who conducted the first study in São Paulo's Vale do Paraíba, using geoprocessing techniques to study the spatial and temporal distribution of dengue fever, were able to identify a pattern of the outbreak occurring in the city of Cruzeiro in 2006.

This article has the objective of identifying patterns in the spatial and temporal distribution of dengue cases occurring in the city of Cruzeiro in the months of March, April, May and June 2006, compared with the same months in 2011. The two years chosen can be justified by the occurrence of outbreaks, and the months listed correspond to the period with the greatest incidence of cases.

\section{Methods}

The area under study refers to the city of Cruzeiro located at the far eastern end of the state of São Paulo, in the region known as Vale do Paraíba; latitude $22^{\circ} 33^{\prime}$ South and longitude $44^{\circ} 60^{\prime}$ 'West, at an altitude of 514 meters, occupying $331 \mathrm{~km}^{2}, 36 \mathrm{~km}^{2}$ of which constitutes urban area, and $295 \mathrm{~km}^{2}$ rural area (Figure 1). ${ }^{9}$

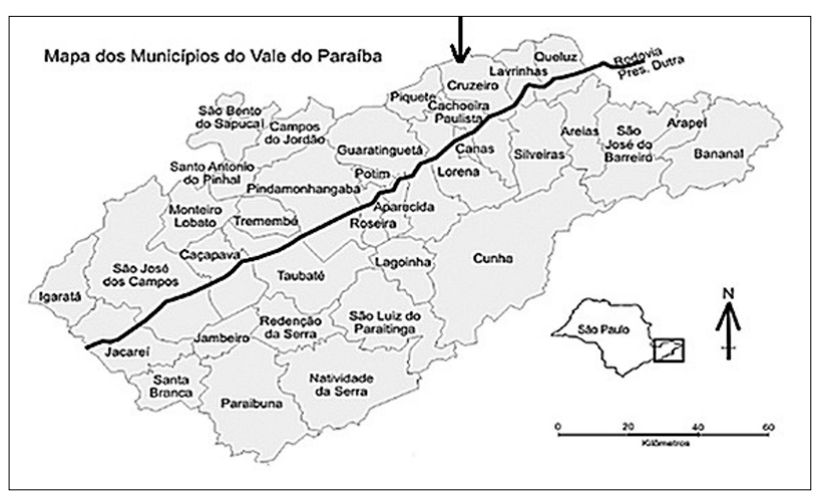

FIGURE 1 Location of the city of Cruzeiro with territorial boundaries and highlighting the Presidente Dutra Highway. ${ }^{10}$

The climate is tropical (hot and humid), with temperatures varying between 20 and $27^{\circ} \mathrm{C}$. The hottest months are from November to April, and the coldest between May and October. Rain is most present between December and March, with January being the wettest month. The driest period is covered between the months of June and September.

The cases of dengue fever occurring in the city are notified to the Municipal Epidemiological Surveillance sector and confirmed by laboratory or clinical-epidemiological criteria in accordance with guidelines from the Ministry of Health. ${ }^{11}$
The ecological and exploratory study consisted in listing the cases of dengue fever reported and confirmed, identifying the address and the date of onset of the first symptoms, and distributing the data on the city map in accordance with the 96 census sectors for the year 2000 provided by the Brazilian Institute of Geography and Statistics (available at: downloads.ibge.gov.br/downloads_ geociencias.htm).

The following approach were used to verify the association between the incidence of dengue, and mapping of cases in the years 2006 and 2011 for the months of March, April, May and June; spatial statistical analyses were used to check for autocorrelation using the Local and Global Moran's I and the Kernel estimator.

To identify the presence of spatial autocorrelation, the Global Moran's I was used $\left(I_{M}\right)$, which analyzed if there were any sector clusters with high rates, and clusters with low rates. The $\mathrm{I}_{\mathrm{M}}$ varies between -1 and +1 and may be attributed a significance level ( $\mathrm{p}$-value), considering the rates of each census sector in relation to the rates of neighboring sectors, and the average of this rate.

Once calculated, it is important to establish its statistical validity, estimating its significance. If this value corresponds to an extreme simulation of a distribution, it is a value with statistical significance. The closer to 1 (one), the greater the similarity between neighbors. The value 0 (zero) indicates that there is no correlation, and negative values indicate dissimilarity. The public domain application TerraView developed by the Image Processing Division (DPI) of the National Institute of Spatial Research was used (available at: www.dpi.inpe.br/terraview/index.php).

The Kernel estimator, as stated, evaluates the events using analysis units. Taking into account that the population data is grouped and the official minimum grouping unit is the census sector, when attributing the known population data to the centroid of the region, there is the possibility of estimating the intensity of this process (population) using a Kernel function. The darker areas (hot spots) correspond to the higher density of cases.

\section{Results}

691 cases of dengue fever were georeferenced in the year 2006 (rate of 864.2 cases $/ 100,000$ inhabitants). The first cases were identified in the central region, and the latter cases in the north, northeast and central region. In the month of March, 35 cases were registered, varying from 0 to 7 per census sector, while in April 358 cases were recorded, varying from 0 to 20, 271 cases in May, varying from 0 to 15, and 23 cases in June, varying from 0 to 3 cases per census sector. It was not possible to identify the address of four confirmed cases as this was not completed in the notification form. 
Thematic maps with the distribution of cases (Figure 2 ), according to the months of the year in 2006, show that the first cases occurred in March, in the central and eastern region, on the banks of the Paraíba do Sul river and its effluent stream, called Córrego da Barrinha, also following the route of the railroad that cuts the central region of the city and highway linking Cruzeiro to Lavrinhas. In the month of April, cases appear in practically all census sectors, heading to the south, southeast, central region and northeast. In May, 76 (79\%) census sectors had at least 1 case of dengue fever, with the highest number of cases in the central, south, southeast and east regions, following the course of the Paraíba do Sul river and Córrego da Barrinha stream. In June, only two sectors presented 3 cases, located in the north/northeast and central/south regions.

The Global Moran's I and respective p-values for March, April, May and June are shown in Table 1. It can be seen that the Global Moran's I was significant in the months of April and May, with a positive autocorrelation.

In 2011, 654 cases of dengue fever were georeferenced (rate of 886.8 cases $/ 100,000$ inhabitants). The first cases also occurred in March, in the north, northeast, central, south and southeast regions, with latter cases occurring in the north region. In the month of March, 70 cases were registered, varying from 0 to 14 per census sector, while in April, 292 cases were recorded, varying from 0 to 24, 279 cases in May, varying from 0 to 26, and 13 cases in June, varying from 0 to 2 cases per census sector. It was not possible to identify the address of 55 confirmed cases. The impossibility of geocoding these cases was due, above all, to the absence or insufficiency of data contained in the Sinan database and failure to complete the Notification Form.

\begin{tabular}{|c|c|c|c|c|}
\hline Months & Moran 2006 & p-value & Moran 2011 & p-value \\
\hline March & 0.08 & 0.09 & 0.23 & 0.01 \\
\hline April & 0.28 & 0.01 & 0.16 & 0.05 \\
\hline May & 0.20 & 0.01 & 0.05 & 0.24 \\
\hline June & 0.01 & 0.46 & 0.08 & 0.09 \\
\hline
\end{tabular}

The thematic maps with distribution of cases (Figure 2), according to the months from the first half of 2011, show that the first cases occurred in March, near to the banks of the Paraíba do Sul River, and the Cruzeiro-Passa Quatro and Cruzeiro-Lavrinhas highways. In the month of April, the cases are located in the Central, South, North, Northwest and Northeast regions, taking over the entire urban extent of the city. In May, 80 (83\%) of the census sectors had at least 1 case of dengue. In the month of June, only one sector presented more than one case of dengue fever, situated in the north region.

The Global Moran's I and respective p-values for March, April, May and June 2011 are shown in Table 1. Note that the Global Moran's I was significant in the months of March and April, with a positive autocorrelation and significance.

In March 2006, the highest density of cases occurred in the Central and North regions, as demonstrated by the Kernel estimator. In the months of April and May the highest density occurred in the North, Central and South regions. In June, the hot spot manifested in the Central, North, Northeast, Northwest and Southeast regions (Figure 3).

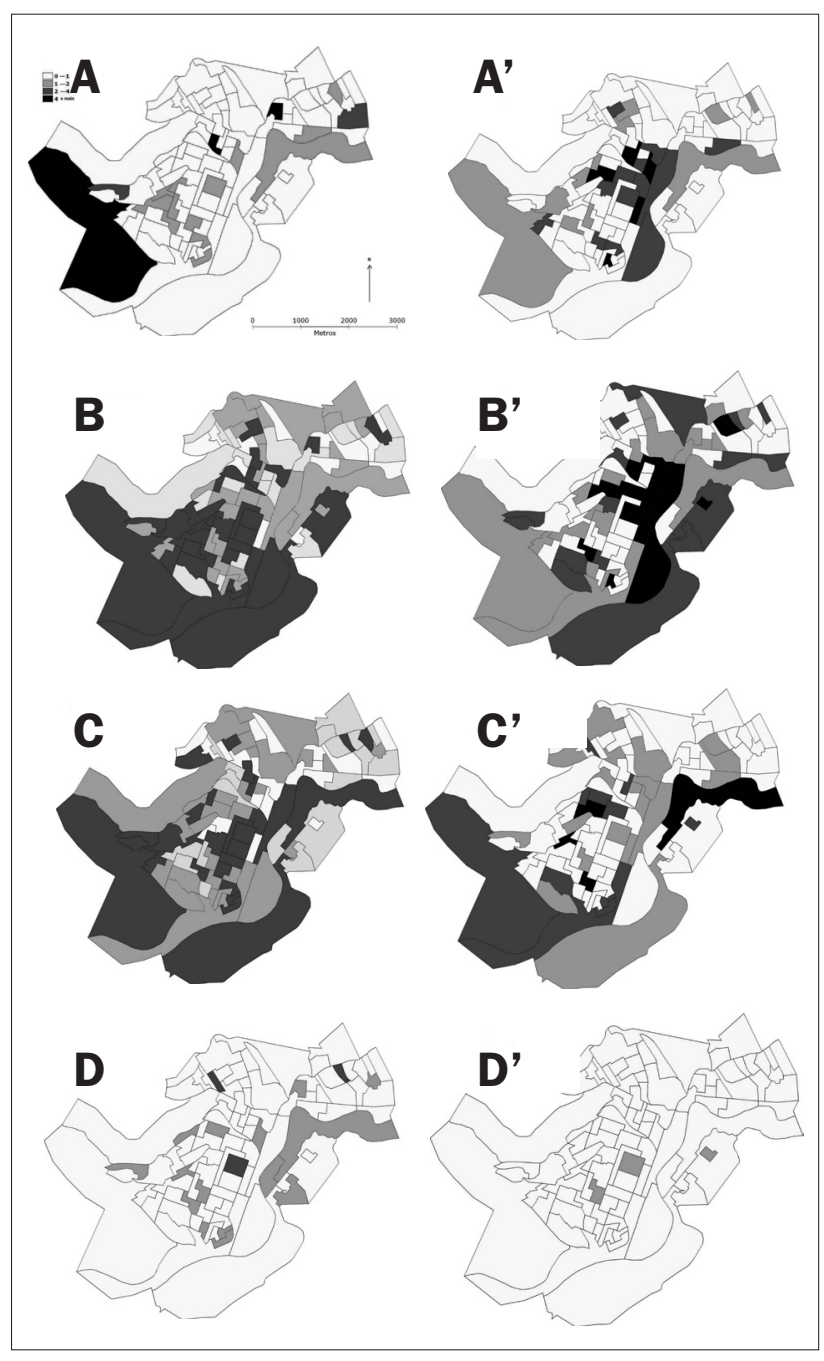

FIGURE 2 Distribution of cases of dengue according to census sectors occurring in the months of March (A), April (B), May (C), and June (D) 2006, and in the months of March (A'), April (C'), May (C') and June (D') 2011, Cruzeiro, 2006 and 2011. 


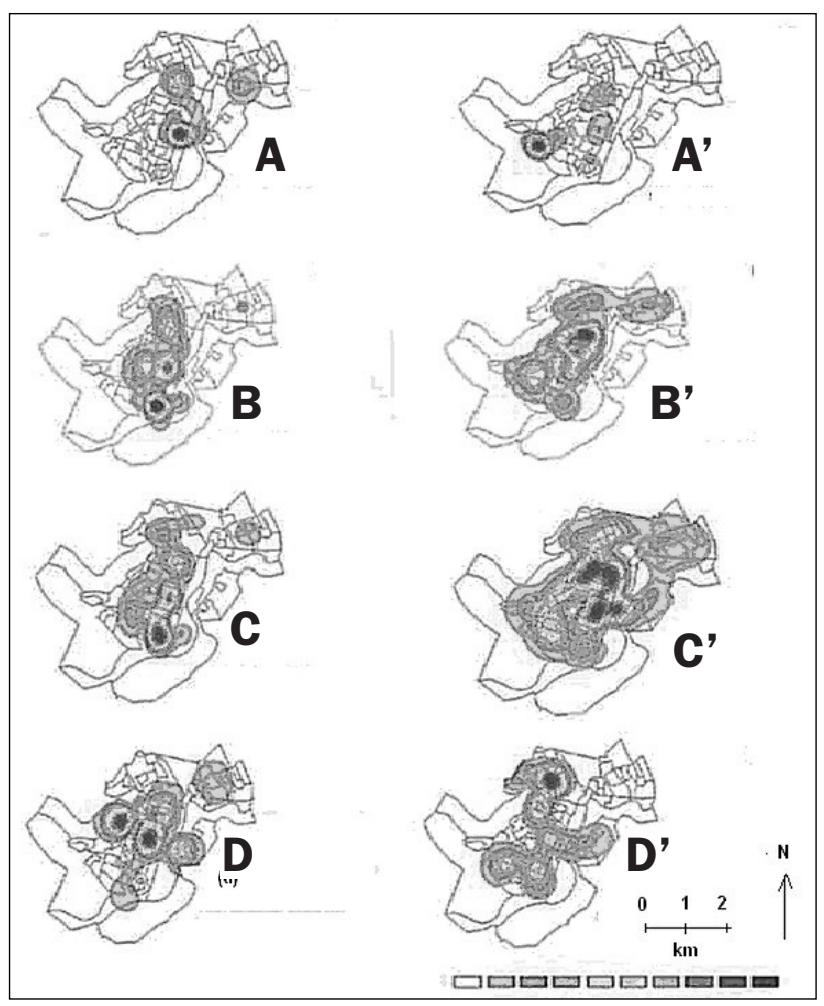

FIGURE 3 Comparative thematic maps with the Kernel estimator of the distribution of cases of dengue notified and confirmed in the months of March (A), April (B), May (C), and June (D) 2006, and in the months of March (A'), April (B'), May (C') and June (D') 2011, Cruzeiro, 2006 and 2011.

The month of March 2011 presented the highest density in the west region. In April, the hot spot was concentrated near to the Central region, facing north. In May, the highest density occurred in the Central region, spreading a little to the East, North, Northeast and Nest. In the month of June, the hot spot moved to the north-south region (Figure 3).

\section{Discussion}

In this study, conducted at two different times using geoprocessing techniques, it was possible to identify a spatiotemporal pattern of dengue outbreaks occurring in Cruzeiro in 2006 and 2011.

The introduction of the dengue virus in Cruzeiro produced two large scale waves of outbreaks in the classic form of the disease. The risk of occurrence of these outbreaks was foreseeable owing to the intense circulation of the virus in the region, as well as the incidence of the disease in neighboring cities.

The infestation of the mosquito that transmits the dengue virus, population density and the lack of group immunity against this agent can be identified as possible factors that led to the occurrence of the outbreaks, not only in the first wave, which occurred explosively, but also in the second, which had the highest incidence rate ( 864.2 and 886.8 cases per 100,000 inhabitants).

At both times, the outbreak began in one region, spreading to almost all regions of the urban area, following the banks of the Paraíba do Sul river, highways and railways cutting across the city and responsible for the large circulation of people, products and vehicles. This trend was also noted in a study conducted in the city of Tupã, state of São Paulo.?

In the month of April there was a sharp increase in the notification and confirmation of cases, possibly as a consequence of the presence of breeding sites in urban areas, susceptible population, high temperatures and heavy rainfall.

The quarterly coverage of the "House to House" program in the city was reached by disease control agents in almost the entire city. Even so, there were dengue fever outbreaks in the years 2006 and 2007. ${ }^{12}$

In the Cruzeiro outbreaks, an explanation for the occurrence of cases concentrated in different regions of the city could perhaps be due to the decrease in susceptibility in the region where a larger number of cases occurred, thereby shifting the concentration of the outbreak to another area.

In this study, fewer new cases were registered from the month of June onward, with milder temperatures and lower humidity levels recorded. This strongly suggests that the adverse climate conditions for proliferation of the vector have an important role in the transmission of the disease in the city. ${ }^{13}$

Three factors should be considered in the decrease in the number of cases in the outbreak: depletion of susceptible individuals; vector control interventions and unfavorable natural conditions, such as lower temperature and humidity, thereby reducing the vector population; and good sanitation conditions. Poorer areas that have good basic sanitation conditions may have the same levels of infestation as more affluent areas. On the other hand, areas with high coverage of water supply services and higher agglomeration of people in the same residence present higher concentrations of the vector. ${ }^{14}$ In relation to susceptible individuals, it has been suggested that in 2006 only one type of virus circulated in the region, serotype DEN-3, and therefore people became immune after contact with the virus, a similar situation to that found in the city of Tupã.? 
In 2011, the circulating serotype was DEN-1, which arose in the city for the first time and was found in the entire susceptible population, including those already sensitive to DEN-3, resulting in another outbreak.

The Global Moran's I applied to the cases of dengue fever occurring in the months of March, April and May of 2006 and 2011 presented positive values, indicating a positive spatial autocorrelation. The values tend to be similar to neighboring sectors, indicating that the occurrence of cases of dengue fever in the city are connected, with a strong relationship between sectors, which is even stronger between nearby neighboring sectors. We must call attention to the fact that the Global Moran's I presented a positive spatial correlation for the months of April and May 2006 and March and April 2011. Only the month of June 2011 presented a negative Global Moran's I, which leads us to believe that there are sectors with high indices of dengue cases surrounded by sectors with low indices, though this did not present statistical significance.

Comparing the maps with the Kernel estimators for the years 2006 and 2011 (Figure 3), it can be noted that the hot spot did not behave in the same manner during the two outbreaks. In 2006, the hot spot began in the central region and moved North-south and East-west, while in 2011, it began in the Center-west region and moved to the Central region and then finally the North-south and East-west regions.

In the months of April and May there was a sharp increase in the notification and confirmation of cases, possibly as a consequence of the presence of breeding sites in urban areas, susceptible population, high temperatures and heavy rainfall. The risk for dengue fever has also been identified in areas with the highest concentration of individuals, high economic diversity, strong population density, high household density, and high density of vacant lots (wasteland) in more remote districts of the central region. ${ }^{15}$

Dengue control measures have been based exclusively on chemical control of the vector to the detriment of important factors modulating the disease transmission dynamics, especially those related to social determinants, such as spatial occupation and living conditions. Therefore, with each introduction of a new serotype there is a new outbreak. ${ }^{15}$

The rapid growth of the urban population provides a major source of susceptible and infected individuals, concentrated in restricted areas. This fact, associated with poor sanitation, housing and cultural factors specific to large urban centers provides the ecological conditions favorable to the transmission of the dengue virus. ${ }^{16}$
Therefore, it is understandable that locations with a higher proportion of urban population may have higher incidences of dengue. ${ }^{17}$ The spatial relationship between the transmission of dengue and other variables, such as the level of immunity of the population, effectiveness of the control measures, degree of infestation by the vector, the habits and attitudes of the population, etc, must be assessed. It is important to reiterate that the studies using spatial location approaches and use of GIS, although recent in the scope of health sciences, have gradually become indispensable for the analysis of disease determination. ${ }^{15}$

Despite epidemiological surveillance guidelines for dengue fever, when investigating the probable locations of infection considering residence, workplace and travel, in the investigation form standardized by the Ministry of Health, only data referring to the residential address are structured to allow precise localization of the case. Thus, analyses considering the patient's address as the risk factor exposure site assume that individuals are immobile and ignore any possibility of exposure at other places, for example, work or leisure environments. ${ }^{18}$

With the use of information originating from public health services only, it is possible for some of the cases not to be computed, in addition to the occurrence of cases whose clinical manifestation are discreet, leading to underreporting. Other sources of errors can be considered, such as disappearance of exam results, undetermined diagnoses and failure to locate addresses.

Difficulties encountered in the georeferencing of reported cases of the disease, due to address problems, prevented the location of cases in census sectors. ${ }^{1,5}$ We cannot say where the focus of infection is exactly, since people can either have contracted the disease in their own homes, or at work, while in transit or anywhere else in the city. Even with the difficulties described above, the prompt location of cases or the aggregation of information in small areas, such as census sectors, can be quite enlightening. ${ }^{18}$

The evaluation of different exposures to the factors involved in transmission allows us to identify geographic areas with a higher risk of infection, and this is fundamental to the development of programs for the prevention and control of dengue fever. ${ }^{19}$

\section{Conclusion}

It can be concluded that by using the geoprocessing technique, it was possible to map the address of people's homes affected by dengue outbreaks occurring in Cruzeiro in 2006 and 2011, as well as to show how the disease 
spread through the city on these two occasions, bearing in mind the presence of two different viral serotypes and the susceptibilities of the individuals.

\section{Resumo}

Descrição espaço-temporal das epidemias de dengue em Cruzeiro, SP, em 2006 e 2011.

Objetivo: identificar padrões na distribuição espaço-temporal dos casos de dengue ocorridos no município de Cruzeiro, SP.

Métodos: foi desenvolvido um estudo ecológico e exploratório utilizando ferramentas de análise espacial e com dados de casos de dengue obtidos do SinanNet. Foi feita uma análise por área, tomando-se como unidade o setor censitário do Instituto Brasileiro de Geografia e Estatística (IBGE). Foram analisados os meses de março a junho de 2006 e 2011, que mostraram o avanço da doença. Utilizou-se o programa TerraView 3.3.1; foram calculados os índices de Moran global, mês a mês, e o estimador de Kernel.

Resultados: no ano de 2006, foram georreferenciados 691 casos de dengue (taxa de 864,2 casos/100 mil hab.); os índices de Moran e $\mathrm{p}$-valores foram significativos nos meses de abril e maio $\left(I_{M}=0,28, p=0,01 ; I_{M}=0,20, p=0,01\right)$ com densidades maiores nas regiões central, norte, nordeste e sul. Em 2011, foram geocodificados 654 casos (886,8 casos/100 mil hab.); os índices de Moran e p-valores foram significativos nos meses de março e abril $\left(\mathrm{I}_{\mathrm{M}}=0,28, \mathrm{p}=0,01 ; \mathrm{I}_{\mathrm{M}}=0,16\right.$, $\mathrm{p}=0,05)$ com densidades nas mesmas regiões de 2006. O índice de Moran global $\left(\mathrm{I}_{\mathrm{M}}\right)$ é uma medida global de autocorrelação espacial, que indica o grau de associação espacial no conjunto de informações a partir do produto em relação à média. $\mathrm{O}_{\mathrm{M}}$ varia entre $-1 \mathrm{e}+1$, e a ele pode ser atribuído um nível de significância (p-valor). O valor positivo aponta para uma autocorrelação espacial positiva ou direta.

Conclusão: foi possível identificar padrões na distribuição espaço-temporal dos casos de dengue ocorridos no município de Cruzeiro, SP, e localizar os setores censitários onde a epidemia teve início e como evoluiu.

Palavras-chave: dengue; sistemas de informação geográfica; vigilância epidemiológica; estudo ecológico; distribuição espacial da população.

\section{References}

1. Pontes RJS, Ruffino-Netto A. Dengue em localidade urbana da região sudeste do Brasil: aspectos epidemiológicos. Rev Saúde Pública. 1994;28(3): 218-27.

2. Costa AIP. Identificação de unidades ambientais urbanas como condicionantes da ocorrência de Aedes aegypti (Diptera Culicidae) e de dengue na cidade de São José do Rio Preto, S.P., em 1995. [Dissertação]. São Paulo: Faculdade de Saúde Pública, Universidade de São Paulo; 1995.

3. Serpa LLN, Costa KVRM, Voltolini JC, Kakitani I. Variação sazonal de Aedes aegypti e Aedes albopictus no município de Potim, São Paulo. Rev Saúde Pública. 2006;40(6):1101-5

4. São Paulo. (Estado). Secretaria da Saúde. Centro de Vigilância Epidemiológica. Dengue. São Paulo, 2011. [citado 1 fev 2011]. Disponível em: http://www. cve.saude.sp.gov.br/htm/zoo/if_sem_den02.htm

5. Galli B, Chiaravalloti Neto F. Modelo de risco tempo-espacial para identificação de áreas de risco para ocorrência de dengue. Rev Saúde Pública. 2008;42(4):656-63

6. Souza-Santos R, Carvalho MS. Análise da distribuição espacial de larvas de Aedes aegypti na Ilha do Governador, Rio de Janeiro, Brasil. Cad Saúde Pública. 2000;16(1):31-42.

7. Barbosa GL, Lourenço RW. Análise da distribuição espaço-temporal de dengue e da infestação larvária no município de Tupã, Estado de São Paulo. Rev Soc Bras Med Trop. 2010;43(2):145-51.

8. Carvalho RM, Nascimento LFC. Spatial distribution of dengue in the city of Cruzeiro, São Paulo State, Brazil: use of geoprocessing tools. Rev Inst Med Trop São Paulo. 2012;54(5):261-6.

9. Cruzeiro. Prefeitura Municipal. Plano Municipal de Saúde 2010-1013. 49p

10. Nascimento LFC, Batista GT, Dias NW, Catelani CS, Becker D, Rodrigues L. Análise espacial de neonatal no Vale do Paraíba, 1999 - 2001. Rev Saúde Pública. 2007;41(1):94-100.

11. Brasil. Departamento de Operações, Fundação Nacional de Saúde, Ministério da Saúde. Manual de dengue: vigilância epidemiológica e atenção ao doente. Brasília (DF): Departamento de Operações, Fundação Nacional de Saúde, Ministério da Saúde; 1995.

12. Chiaravalloti-Neto F, Costa AIP, Moura MSA, Soares MRD, Pereira FC, Battigaglia M, et al. Avaliação de ações municipais de combate a vetores da dengue na região de São José do Rio Preto, São Paulo, 1989 a 1995. Rev Soc Bras Med Trop. 1999;32(4):357-62.

13. Gubler DJ, Clark GG. Dengue/dengue hemorrhagic fever: the emergence of a global health problem. Emerg Infect Dis. 1995;2(1):55-7.

14. Mondini A, Chiaravalloti-Neto F. Variáveis socioeconômicas e a transmissão de dengue. Rev Saúde Pública. 2007;41(6): 923-30.

15. Flauzino RF, Santos RS, Oliveira RM. Dengue, geoprocessamento e indicadores socioeconômicos e ambientais: um estudo de revisão. Rev Panam Salud Publica. 2009;25(3):456-61.

16. Costa AIP, Natal D. Distribuição espacial da dengue e determinantes socioeconômicos em localidade urbana no Sudeste do Brasil. Rev Saúde Pública. 1998;32(3):232-6.

17. Teixeira MG, Costa MCN, Barreto ML, Mota E. Dengue and dengue hemorrhagic fever epidemics in Brazil: what research is needed based on trends, surveillance, and control experiences? Cad Saúde Pública. 2005;21(5):1307-15.

18. Almeida MCM, Assunção RM, Proietti FA, Caiaffa WT. Dinâmica intraurbana das epidemias de dengue em Belo Horizonte, Minas Gerais, Brasil, 1996-2002. Cad Saúde Pública. 2008;24(10): 2385-95

19. Almeida AS, Medronho RA, Valencia LIO. Análise espacial da dengue e o contexto socioeconômico no município do Rio de Janeiro, RJ. Rev Saúde Pública. 2009;43(4):666-73. 